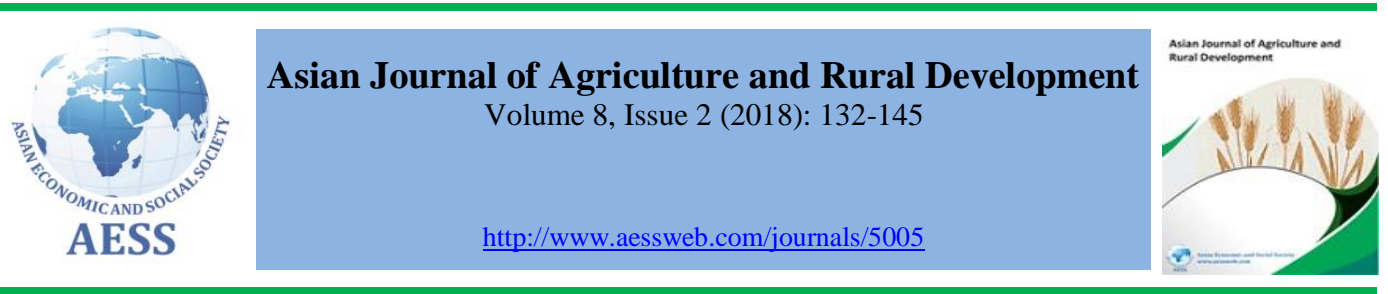

\title{
THE ROLE OF GOVERNMENT IN AGRICULTURAL AND RURAL DEVELOPMENT: REVIEW OF AGRICULTURAL POLICIES IN UKRAINE AFTER INDEPENDENCE WITH A LOOK AT THE EU AND SOUTH KOREA EXPERIENCE
}

\author{
Stanislav Rieznik \\ Lee Hwan Beom
}

Department of Public Administration at Yeungnam University, Geyongsan-si, 712-749, South Korea.

\. hblee@ynu.ac.kr (Corresponding Author)

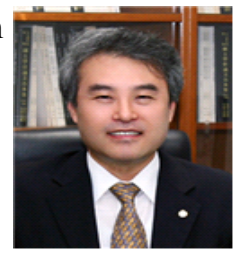

Corresponding Author

\section{ARTICLE HISTORY:}

Received: 09-Aug-2018 Accepted: 13-Nov-2018 Online Available: $30-\mathrm{Nov}-$ 2018

\section{Keywords:}

Ukraine,

Role of government, Agricultural and rural Development

\begin{abstract}
Support for prime agricultural producers in Ukraine has been characterized by high volatility in the last decade, and some recent policy developments have contributed to the volatility and unpredictability. Until recently, the government support for agricultural holdings led to an increase in the export potential of the sector, but, on the other hand, it also brought a number of negative consequences. This study aims at reviewing of the present status of Ukraine's agricultural sector and rural areas and examines the role of the government intervention and support in the transformation of the agricultural sector and its effect on rural development to provide policy recommendations in this regard. Based on the analysis, the study provides policy recommendations suggesting that government need to promote cooperation of small farms and households (helping them to develop in organic agriculture direction) with agricultural holding companies and emphasizes that development of rural non-farm employment opportunities can be seen as a pillar of the rural development policy. In addition, it is necessary to foster organic agricultural development and provide local governments with greater authority in order to achieve sustainable agricultural sector and rural areas development.
\end{abstract}

\section{Contribution/ Originality}

This study contributes to the existed literature providing policy recommendations for agricultural development based on the current state of dualization in the agricultural sector. It also stresses the importance of continuing the decentralization reform for sustainable rural development.

DOI: 10.18488/journal.1005/2018.8.2/1005.2.132.145

ISSN (P): 2304-1455/ISSN (E):2224-4433

How to cite: Stanislav Rieznik and Hwan Beom Lee (2018). The role of government in agricultural and rural development: review of agricultural policies in Ukraine after independence with a look at the EU and South Korea experience. Asian Journal of Agriculture and Rural Development, 8(2), 132-145.

(C) 2018 Asian Economic and Social Society. All rights reserved. 


\section{INTRODUCTION}

Various types of inputs, services, and commercial ties play key roles in modern agriculture. It is clear that the competitiveness of the agricultural sector cannot increase without the development of industrial, commercial, and service sectors characterizing modern agriculture. Therefore, there is an urgent need for policies that can promote technological and human resource development and enhance the attractiveness of rural areas in the private sector, such as roads, electrification, and telecommunications (Norton, 2004). To satisfy quality and safety standards of international markets, modern agriculture requires the proper government intervention that can and should create favorable conditions for cooperation in the agricultural and industrial sectors through appropriate management and administrative/advisory services in the secondary (e.g., processing and agricultural industries) and tertiary (e.g., technical, commercial, and transport services) sectors.

Government support for prime agriculture producers also plays an important role in agricultural development. Support for prime agricultural producers in Ukraine has been characterized by high volatility in the last decade, and some recent policy developments have contributed to the volatility and unpredictability. The Ukrainian government needs to seriously consider the safety and quality of food products and implement a certification system for documenting compliance with internationally accepted standards to take full advantage of its WTO membership and increase exports of agricultural and food products as well as to improve its domestic supply. Ukraine's accession to the WTO and ratification of Ukraine - EU Association Agreement in 2014 has launched the process of development of a qualitatively new form of relations on the principles of political association and economic integration but has created a number of problems that can be solved only through the modernization of agricultural policies and new approaches to domestic support focusing on long-term improvements in productivity and competitiveness and making the agricultural policy more predictable.

There are two major groups in Ukraine's agricultural sector: large agricultural enterprises (about 152 , each with more than 10,000 ha of leased land) and small and medium-sized farmers with rural households accounting for about 50\% of total production volume. State support for large-scale enterprises and opinions of politicians can be divided on the appropriate distribution of resources between these groups. On the one hand, support for high-income groups is more likely to increase tax revenues than that for small and medium-sized farmers, but this comes at the expense of poverty and hardship for the latter group. Till recently government support for agricultural holding companies has led not only to an increase in the export potential of the sector but also to a variety of negative effects such as exports of capital from the real sector to offshore entities, the formation of strong lobby efforts against the introduction of principles of sustainable agriculture based on proper crop rotation and soil fertility and the use of organic fertilizer (FAO, 2012). This lobbying has made use of the market power of big players to ensure preferences for state support and marketing channels (infrastructure and export facilities). For sustainable agriculture, government support with the obligatory fulfilment of requirements and timely government interventions is needed. The Ministry of Agrarian Policy and Food of Ukraine has prepared a draft of a single and comprehensive Strategy for Agriculture and Rural Development 2015-2020 that addresses the real needs of the sector. The Strategy was supported by the National Reforms Council at the meeting on 9 November 2015 (MAPF, 2015). The overall objective of the National Strategy and Action Plan for Agriculture and Rural Development for the period 2015-2020 is to increase agricultural competitiveness and food security, and to promote rural development in a sustainable manner in line with EU and international standards. Based on the analysis below, this paper suggests that the Ukraine government agricultural policy should focus on the whole sector and ensure that small and medium-sized farmers have an opportunity to modernize and access agricultural markets while using available resources and funds. In order to achieve sustainable agricultural sector and rural areas development Ukrainian government should make its agricultural support stable, transparent 
and predictable and establish clear targets and mechanisms to ensure that all types of agricultural producers receive the necessary support in the most appropriate way.

\section{PRESENT STATUS OF UKRAINE'S AGRICULTURAL SECTOR AND RURAL AREAS}

This paper identifies the main problems in Ukraine's agricultural sector and finds certain aspects of its agricultural and rural development policies that need to be considered and analyzed. These issues include (a) state-funded support programs with limited transparency that favor big agricultural enterprises, which accentuates inappropriate policies and non-sustainable agricultural practices, and (b) the absence of a proper rural development policy, which produces high rural unemployment, decaying social infrastructure systems in rural areas, and depopulation.

The Ukrainian government is clearly responsible for these problems and the present state of development. As a representative example, Ukraine did not have a long-term strategy for the use of budgets for agricultural and rural development till 2013. Thus, inappropriate and inconsistent policies have made long-term investment planning by agricultural enterprises in the sector very difficult and increased their entrepreneurial risk. It should be noted that, following the demise of the U.S.S.R., the process of the economic transition to a market economy has been difficult for Ukraine's agricultural sector. Food and agricultural sectors fell into a deep crisis from 1990 to 1999. During this period, the output of the primary agricultural sector in Ukraine declined sharply by $51 \%$ (OECD, 2004). The crisis essentially came about as a result of a collapse of the general economy after a breach of economic relationships within the Soviet infrastructure, but the depth and length of the decline were more serious than in other transition economies because of the government inert and passive policy reforms for most of the 1990s.

\subsection{The current state of dualization in agricultural sector}

The agrarian sector of Ukraine is currently represented by large corporate farms and small individual farms that range from households to farm cooperatives jointly managed by several families and small corporations. The absence of a proper strategy for decades, an incomplete land reform initiative, and weak government control over the development of the agricultural sector have led to the concentration of land and assets and the consolidation of large holding companies. This process has been taken place mainly in the shadow and been possible due to no transparent control of the distribution of former collective enterprises' property and agricultural land. Emergence of an informal land market led to the consolidation of large areas of farmland in the hands of vertically integrated legal entities and individuals through the leases, lease-purchase contracts, and purchase agreements. Hundreds of thousands of hectares of consolidated land have been cultivated by export-oriented corporations. In 2010, the 40 largest holding companies controlled 4.5 million ha of land (now about 6 million ha), accounting for $11 \%$ of total agricultural land. Large corporations and mega agricultural holding companies rarely register their businesses in Ukraine because they prefer offshore registration option to benefit from tax exemptions (Deininger and Byerlee, 2012). Therefore, it is difficult to track and statistically measure their emergence and dynamics. During the 2005-2012 period, export of food and agricultural products had increased by $315 \%$ (in 2013, exports of agricultural products in Ukraine amounted to about \$17-18 billion), and Ukraine is now one of the largest grain exporters in the world, but ordinary farmers receive no benefit from it (Sarna, 2014).

More than 40,000 small and medium-sized farms only dream of large profits. There are many international and Ukrainian experts who acknowledge unequal business opportunities for agricultural operators of different sizes in Ukraine. Indeed, large agricultural holding companies have access to comparatively cheap loans in international financial markets, whereas small farmers have to borrow from local banks at an interest rate around 20\%. A serious problem for small and medium-sized Ukrainian farmers in comparison to agricultural holding companies is the 
bureaucratic obstacle (corrupt public services). In terms of subsidies for primary producers, the situation is such that state financial support exists only for large-scale enterprises, whereas governments of developed countries generally provide subsidies mainly to small farmers. Based on the statistics for the agricultural sector as of 2010, small farms accounted for about $55 \%$ of total agricultural production (see Table 1), including $97.4 \%$ of potatoes, $83.6 \%$ of fruits and $88.1 \%$ of vegetables, $80.3 \%$ of milk, and $44.9 \%$ of meat. Large farms (agricultural holding companies) remained strong in traditional crop exports, accounting for $78 \%$ of national agricultural production and $84 \%$ of the total national production of sunflower seeds (Keizer et al., 2012). This shows that small farmers are an important part of the national economy and that they require and deserve government support.

Table 1: Share of different types of farms in agricultural production, $\%$

\begin{tabular}{lcccccc}
\hline \multirow{2}{*}{ Indicator } & \multicolumn{3}{c}{ Corporate farms } & \multicolumn{4}{c}{ Individual farms } \\
& $\mathbf{2 0 0 0}$ & $\mathbf{2 0 1 0}$ & $\mathbf{2 0 0 0}$ & $\mathbf{2 0 1 0}$ & $\mathbf{2 0 0 0}$ & $\mathbf{2 0 1 0}$ \\
\hline Gross agriculture output (value) & 32.3 & 39.9 & 1.7 & 5.0 & 66.0 & 55.1 \\
Production (quantity) & & & & & & \\
Grain and leguminous crops & 76.5 & 63.8 & 5.1 & 12.0 & 18.4 & 24.2 \\
Sunflower seed & 77.5 & 64.7 & 10.0 & 17.8 & 12.5 & 17.5 \\
Rapeseed & 96.0 & 85.0 & 4.0 & 15.0 & - & - \\
Sugar beet (for processing) & 82.1 & 83.7 & 5.7 & 8.4 & 12.2 & 7.9 \\
Potatoes & 1.1 & 1.7 & 0.3 & 0.9 & 98.6 & 97.4 \\
Vegetables & 15.5 & 9.3 & 1.4 & 2.6 & 83.1 & 88.1 \\
Fruits and berries & 18.2 & 16.4 & - & - & 81.8 & 83.6 \\
All types of meat & 25.8 & 52.8 & 0.5 & 2.3 & 73.7 & 44.9 \\
All types of milk & 28.5 & 18.7 & 0.5 & 1.0 & 71.0 & 80.3 \\
Eggs & 33.7 & 59.6 & 0.1 & 0.5 & 66.2 & 39.9 \\
Honey & 6.6 & 2.0 & 0.2 & 0.3 & 93.2 & 97.7 \\
Wool & 38.3 & 13.8 & 0.3 & 3.1 & 61.4 & 83.1 \\
\hline
\end{tabular}

Source: Keyzer et al., 2012

\subsection{An asymmetric development of organic agriculture}

In terms of organic agriculture, by its natural endowment of climate and soil, Ukraine has the potential to become a leading producer of organic products. Organic agricultural production in Ukraine is currently in its initial stages of development, and despite its huge potential, it faces a number of serious problems. The area under organic production covers over 270,000 hectares, putting Ukraine into the top 20 leading producers of organic products and the first place among Eastern European countries (FAO, 2012). In 2010, nearly 120 agricultural enterprises were in operation based on principles of organic farming. All enterprises were internationally certified, and most organic agricultural farms in Ukraine were large or medium-sized entities with an average size of 3,000 ha. Major forms of organic production include grain, legumes, and oilseeds. About $70 \%$ of all organic products are sold for exports, but their share of the domestic market is growing (cereal, juices, honey, and others). The Federation of Organic Movement was formed in 2005 and has over 100 members composed of businesses, small farmers, and public/state research organizations (UNEP, 2011). In 2009, the national certification organization "Organic Standard" received international accreditation. However, the problem is that production of organic cattle remains almost non-existent, and a processing industry for organic agricultural products is yet to be developed. Such one-sided development of organic agricultural products reduces profits of agricultural producers.

Ukraine's slow and asymmetric development of organic production is caused by the following factors: 
- Weak state support and stimulation systems for the development of organic agricultural products,

- Incomplete legal and normative standards,

- Export domination and the underdevelopment of the home market,

- The active production and exportation of only one or two types of organic raw agricultural products (corn and oil) and the weak production of other crops,

- Most large agricultural enterprises involved in organic production and the limited transition of small and medium-sized enterprises.

\subsection{Limitations of the local governments}

Another problem lies in the sphere of government administration. Ukraine's administrative and territorial structure of the territorial subdivision system has not changed much since its independence in 1991 and is far from reflecting good governance in terms of global normative understanding. The current spatial division reflects political principles of a territorial organization inherited from the Soviet era. In Ukraine, large numbers of local authorities (more than 12,000) and districts (500) represent a serious obstacle to effective management and control, causing excessive diversity across departments at the same level and discrepancy between responsibilities and capacities of various organizational units. In sum, it is difficult to efficiently divide government responsibilities and achieve cooperation between government units at various levels. This has created considerable difficulty in achieving coordination between legislative and executive authorities at the local level. In addition, the current system has inherent problems such as ambiguous and ineffective political and administrative relationships between government units at various levels, which can cause serious conflicts of interest, particularly at regional and subregional levels (Maynzyuk and Dzhygyr, 2008). Therefore, decentralization and reform of local governments became the most important task when the window of opportunity has opened. On April 1, 2014 the Cabinet of Ministers of Ukraine government has adopted the concept of reform of local self-government and territorial organization of power. As noticed by Hanushchak et al. (2017), currently local authorities receive much higher revenues through the redistribution of tax income from the central state budget to municipal accounts. In order to increase the institutional and financial capacity of local governments, the government initiated a process of voluntary unification of small districts into administratively more powerful and large structural subdivisions, called "amalgamated territorial communities" (ATC). At present, new capable communities are created by uniting urban and rural communities on a voluntary basis (Lukerya and Halushka, 2016). Thus, there is a hope that the reform of decentralization will continue and contribute to changing the post-Soviet model of relations between the state and society.

\subsection{Rural development}

Since 1991, the role of agriculture in ensuring the development of rural areas has undergone drastic changes. Agricultural policy vector had gradually reoriented on support of large-scale, export-oriented agricultural enterprise development that specialized in production of extensive crops with minimum labor. So far, the agricultural sector is not in a position to fully meet the social and economic needs of rural society (see Table 2). The employment system, formed in rural areas due to the economic conditions of the rural labor market, threatens the ability of the rural population to provide themselves with an adequate quality of life (Kutsmus et al., 2017). 
Table 2: Role of agriculture in rural development in Ukraine

\begin{tabular}{lccccccc}
\hline Indicators & $\mathbf{1 9 9 0}$ & $\mathbf{1 9 9 5}$ & $\mathbf{2 0 0 0}$ & $\mathbf{2 0 0 5}$ & $\mathbf{2 0 1 0}$ & $\mathbf{2 0 1 5}$ & $\begin{array}{c}\mathbf{2 0 1 5} \text { to } \\
\mathbf{1 9 9 0 , + -}\end{array}$ \\
\hline $\begin{array}{l}\text { Number of agricultural } \\
\text { employees, thousand people }\end{array}$ & 4,881 & 3,801 & 2,475 & 1,038 & 595 & 417 & $-4,464$ \\
$\begin{array}{l}\text { Number of employed in private } \\
\text { households, thousand people }\end{array}$ & 681 & - & 2,233 & 2,785 & 451 & 2,372 & 1,691 \\
$\begin{array}{l}\text { Ratio of wages in agriculture to } \\
\text { the average for the economy, \% }\end{array}$ & 90.2 & 50.7 & 48.3 & 51.5 & 63.9 & 63.3 & -26.9 \\
$\begin{array}{l}\text { The share of revenues from } \\
\text { subsidiary farming households } \\
\text { in total resources, \% }\end{array}$ & 10.2 & 31.9 & 48.3 & 28.2 & 23.8 & 22 & 11.8 \\
\hline
\end{tabular}

Source: Kutsmus et al. 2017

As a result of reform in agriculture sector, Ukraine's rural areas have faced a systemic crisis: (a) worsening demographic trends, (b) decreasing living standards, (c) high level of unemployment, (d) deteriorating social service infrastructure systems, and (e) reduced access to social services. The reform program has narrowed the circle of socially oriented participants in rural development and made large-scale farms to focus on business activity and profits, which required a disclaimer of rural social services. As part of their restructuring, agricultural enterprises had to dispose their social assets and transfer responsibility for social service and infrastructure systems to local councils. Initially, the process moved slowly because the government was unable to provide local councils with necessary budgets, and the situation has not changed. The limited financial resources of local budgets do not allow to provide an adequate level of maintenance of infrastructure facilities. Due to the low diversification of sources of income and business activity, the poor maintenance of rural areas and, there is a significant gap in the living conditions of the rural and urban population which provokes a constant influx of young people into cities, and distortion of the age and gender structure of the rural population. Hidden unemployment (e.g., marginally employed people on household land plots) is assessed at about 1.4 million or about $50 \%$ of the total rural workforce. According to an assessment by the Ukrainian Institute of Agrarian Economy, salaries in the agricultural sector are $40 \%$ lower than the national average monthly income. In addition, $16.8 \%$ of all rural households are living below the poverty level, and $48.8 \%$ survive on minimal income (FAO, 2012). A majority of households in Ukraine are still based on manual labor for land cultivation. For instance, their share was $89.3 \%$ in 2011 . Here a positive fact is that the proportion of households relying on tractors for crop production increased from $66.9 \%$ in 2005 to $72.7 \%$ in 2011 . However, only a small percentage of rural families performs all technological operations by tractors. The role of horses and oxen for land cultivation has remained essential in the household sector, even though the proportion of households using these animals fell from $33.6 \%$ in 2005 to $31.8 \%$ in 2011 (Moroz, 2013).

To conclude, the most serious problems with Ukraine's agricultural and rural area development can be summarized as follows:

The weak competitiveness of agricultural products and the insufficient development of products of high value demanded by overseas markets; much lower productivity in comparison to the EU; the limited transparency of state-funded support programs favoring big agricultural enterprises, indicating inappropriate policies and unsustainable agricultural practices; hundreds of thousands of small and fragmented households still practicing a semi-subsistence type of farming; underdeveloped market infrastructure systems for handling, storage, packaging, processing, cooling, and distribution; insufficient market-based research and development; incomplete land reform has limited investment opportunities for farmers; the current administrative and territorial 
structure has not changed much since the country's independence; absence of proper rural development policy and, as result, poorly developed rural infrastructure systems.

\section{THE ROLE OF GOVERNMENT IN AGRICULTURAL AND RURAL DEVELOPMENT IN THE EU AND SOUTH KOREA}

The EU is one of the leading producers of agro-food products in the world who plays a key role in ensuring food security. Agriculture combined with other related industries has played an important role in the economic development of EU countries. Currently, it continues to play an important role in the management of natural resources, especially resources such as land and water (OECD, 2010). One of the oldest EU policies supporting farmers and ensuring food security in Europe is a Common Agricultural Policy (CAP) with rural development measures in the core of it.

As a result of comprehensive economic and agricultural development projects that have been undertaken since the 1960s, South Korea could achieve remarkable structural transformation of agriculture, as well as economic development. Continuous public investment in agricultural and rural development areas led to sustainable development and significant structural changes (OECD, 1999). Therefore considering EU and Korean experience in agricultural and rural development is very important for creation of a sustainable agricultural development path.

\subsection{The role of government in agricultural and rural development in the EU}

EU has emphasized social inclusion as a main policy objective and included political and economic integration, focusing on preserving rural communities. The EU's agricultural policy is more oriented on support of small agricultural holding companies. The EU provides substantial state support for its agricultural sector. According to the Organization for Economic Co-operation and Development (OECD), overall support for agriculture in the EU far exceeds that in the major developed economies. This implies that the EU government views agriculture not just from an economic perspective but also from the perspective of the multifunctional role of agriculture in rural development. The EU considers social inclusion as a main policy objective and includes political and economic integration, focusing on preserving rural communities. One key reason for this is that nearly $30 \%$ of the total population of EU member states lives in rural areas, which cover $90 \%$ of the territory (European Commission, 2007). It should be noted that in Ukraine, about $30 \%$ of its population lives in rural areas too.

Since the beginning, members of the EU have realized a need for an effective policy to assist farmers, control agricultural prices, manage their resources and the rural environment, and ensure that Europe has enough safe, healthy, and affordable food. The creation of the European Community through the 1957 Treaty of Rome set a few objectives for agricultural support and growth. In 1962, the common agricultural policy (CAP) was initiated. At first it focused mainly on supporting agricultural prices, increasing productivity, and stabilizing markets. It actually worked too well in that, throughout the 1970s and 1980s, Europe had a food surplus. Farmers were producing too much food, and a revised CAP set quotas to try to control the problem. In 1992, the EU decided that the CAP required a major revision. The new CAP added environmental concerns to its agenda, encouraging farmers to make responsible environmental decisions, preserve the environment and natural resources, and fight climate change. It also emphasized technological growth and changed its focus from price support to direct aid designed to help farmers improve their farms and care for the environment simultaneously. Over the last decade, the CAP has been encouraging farmers (even small ones) to engage in rural development, start organic production, and pay close attention to food quality (Special Eurobarometer, 2014). The long-term objective of the EU's organic agricultural development is to enhance food security, rural development, sustainable livelihood, and environmental integrity by building the capacity of member countries in organic production, processing, certification, and marketing. The EU government pays close attention to sustainable agricultural and rural development and understands that agricultural 
development is crucial for the growth of whole economy. In Ukraine, policy reforms in the agricultural sphere are often made individually, addressing only one issue at a time, but reforms can be more effective if they are designed and implemented jointly as part of an integrated package or strategy for the sector, as in the case of the EU, because such strategies include both a vision of what the sector should look like and a plan for fulfilling the vision. Here the role of the government as the main policymaker, implementer, and controller in this process is important.

One key part of the institutional system of the EU is the local government. Activities of local authorities have considerable influence on the development of the agricultural sector and rural areas. Local governments influence local development in various ways, including expenditures, taxes and duties, laws, and marketing, among others. In rural areas, the role of territorial governments is particularly important because, as it often happens, they are the only institution to act in this area (Kata and Zając, 2007).

\subsection{The role of government in agricultural and rural development in South Korea}

Since the early 1960s, when Korea's economic and social condition was much worse off that in Ukraine in the 1990s and 2000s, the Korean government started developing various state programs and strategies to tackle the urgent poverty problem of farmers. Number of public agencies which have played important roles in the country's economic and social development were established under the Ministry of Agriculture (Kim, 2009). Founded in 1961, the National Agricultural Cooperative Federation (NACF) was established to enhance the social and economic status of its members and to promote balanced development of the national economy. From the midst of 1970s, the government has started providing farmers with grants and affordable loans for the purchase of agricultural equipment to promote agricultural mechanization. In general, Korea's small farmers considered investment in agricultural machinery to not make much economic sense from a microeconomic perspective. However, policymakers believed that mechanization was an urgent task for the development of agriculture and food security. Therefore, the mechanization of agriculture in the country was carried out under a strong government intervention. Strong financial support for grants and low-cost loans were provided to farmers as well as for machine manufacturing, suppliers, repair services, training, vehicle driving and maintenance, and subsidies (or tax exemptions) for agricultural machinery fuel, among others (Im and Jeong, 2014).

As a result of diverse efforts of the government and the integrated value chain finance model of the $\mathrm{NACF} /$ member cooperatives, the number of farm machines has increased sharply in the last several decades (see Table 3 ).

Table 3: Number of major farm machines owned by 100 farm households

\begin{tabular}{ccccccc}
\hline Year & Power tiller & Tractor & Cultivator & Rise trans-planter & Combine & Grain dryer \\
\hline 1965 & 0.0 & 0.0 & 0.0 & 0.0 & 0.0 & 0.0 \\
1970 & 0.5 & 0.0 & 0.0 & 0.0 & 0.0 & 0.0 \\
1975 & 3.6 & 0.0 & 0.0 & 0.0 & 0.0 & 0.0 \\
1980 & 13.4 & 0.1 & 0.0 & 0.5 & 0.1 & 0.0 \\
1985 & 30.6 & 0.6 & 0.0 & 2.2 & 0.6 & 0.2 \\
1990 & 42.5 & 2.3 & 2.9 & 7.8 & 2.5 & 0.7 \\
1995 & 57.9 & 6.7 & 16.0 & 16.5 & 4.8 & 1.9 \\
2000 & 67.9 & 13.8 & 27.4 & 24.7 & 6.3 & 4.0 \\
2005 & 64.4 & 17.9 & 30.8 & 26.1 & 6.8 & 5.5 \\
2006 & 64.5 & 19.0 & 32.1 & 26.1 & 6.9 & 5.9 \\
2007 & 64.3 & 20.3 & 34.2 & 26.2 & 7.1 & 6.2 \\
\hline
\end{tabular}

Source: Kim, 2009 
The rate of mechanized farming practices in rice farming reached $95 \%$ in the 2000 s for land preparation, transplanting, and harvesting. In addition, farm mechanization in producing upland crops and livestock has shown remarkable progress, as indicated by examples such as robots being used for milking by many dairy farmers. In South Korea and EU, for small farms with a land plot of approximately 50 hectares of arable land, the amount of equipment per unit of land is up to 25 times greater than that for large farms with more than 1000 hectares of arable land (Kalinchyk, 2013). Thus, farmer can become competitive only through cooperatives and machinery use.

A number of recent international agreements such as the Free Trade Agreement between the EU and South Korea, the Free Trade Agreement between the USA and Korea and other FTAs with more than 50 countries in total have affected Korean agriculture, which is represented by a smallscale family farming. One of the key challenges for policymakers is the income gap between farm and urban households. Recent decades have witnessed the widening of this gap. Average farm household income was only 58\% of urban household income in 2012, reflecting the almost smallest share among all OECD countries. Providing farm households with additional sources of income is a key challenge being addressed by Korean policymakers. The Korean government has implemented a series of agricultural policy reforms in the last two decades to cope with significant changes in both international and domestic environments. To strengthen agricultural competitiveness, the government has implemented a number of agricultural programs designed to reduce production costs through farm consolidation, foster competitive farm entities, encourage farmers to specialize, and promote the development of agricultural technologies. In addition, major policy initiatives have been implemented to improve farm household income through direct agricultural payment and crop insurance programs (Im and Jeong, 2014). The Ukrainian government should consider all these important factors in agricultural and rural development in the EU and South Korea and clearly recognize the important role played by the government in achieving prosperity and sustainability through this process.

\section{DISCUSSION AND POLICY RECOMMENDATIONS}

Agricultural and rural development policies of the EU and Korea generally correspond to national priorities as well as to the social and political objectives and thus help to achieve economic as well as non-economic goals. Therefore, the basis of Ukraine's agricultural policy should laid in the achievement of broader social and public objectives for agriculture and rural areas and linked to the promotion of human development. In rural development, the EU and South Korea have demonstrated that the main objectives are to accelerate reductions in the income gap between poor and rich regions, enhance employment, and reduce social disparity. Based on the review of agricultural and rural development policies of the EU and South Korea, it is seen that the main role of the government lies in protecting property rights, enforcing contractual obligations to foster competition in the sector, and providing public goods such as agricultural research, technologies, information, and infrastructure systems to all types of farmers. In addition, stabilizing prices, absorbing diverse risks facing agricultural producers, and providing affordable credit to small and medium-sized farmers can be added.

Despite such a difficult situation and problems facing now by Ukraine's agricultural sector and rural areas, the Ukrainian government still has a chance to mitigate the degeneration of rural areas and achieve sustainable development of the agricultural sector. If the country's tremendous agricultural potential is taken into account, together with the high quality and availability of arable land and natural conditions, then the following solutions and opportunities need to be considered:

- EU Association Agreement opens up of new markets and provides an opportunity for Ukraine to become one of the largest producer of organic products in Europe. Also, modernization of a quality management system could promote access to the new international markets for products of high value, 
- The completion of land reform and formation of an effective land market could create new opportunities in the agricultural sector which along with improvement of the investment and business climate will increase investments in the sector from both local and foreign sources.

- Development of roads and social infrastructures in rural areas will contribute to promotion of business activities in rural areas and additional income. To ensure a balanced level of agricultural and rural development, establishment of mechanisms which allow local authorities to accumulate budgets for the development of necessary social infrastructure systems is necessary (Kolodiy, 2013).

Below alternative policy regarding sustainable Ukraine's agriculture and rural development will be proposed.

\subsection{Regarding dualization in agricultural sector}

Given that Ukraine already has a dual agricultural system, the agricultural development policy need to be designed based on support of both: agricultural holding companies and small and medium-sized farmers. The reason for Ukrainian government to support the development of small and medium-sized farmers and the family farm model in conjunction with large-scale farming is that big agricultural holding companies are engaged in export activities and produce mainly commercially attractive and export-oriented products, whereas small and medium-sized farmers and individual farms produce food products for the domestic market, accounting for about $60 \%$ of total gross product in agriculture, and can continuously develop in organic agriculture direction (Keyzer et al., 2012). Here the Ukrainian government should develop an effective system of collaboration with agricultural holding companies providing opportunities for development and overseeing their activities. Agricultural holding companies and farmers in Ukraine work separately and compete with each other, and this brings problems to some and the loss of benefits to others.

Many rural households have cows, but facing problems with storing and selling of milk and dairy products. Someone needs to collect milk and deliver it to a dairy plant, and this role can be played by a service cooperative. Such cooperatives can collect and cool milk and also manage quality control. In addition, many households and farmers grow vegetables, but the problem is that there are no storage facilities to store the harvest and purchase prices are low even when they should be high. This raises the question of how farmers can be helped and how small and medium-sized producers can access markets and services. Here a solution lies in cooperation between farmers and agricultural holding companies. Service cooperatives can collect milk, fruits, and vegetables and deliver them to dairy plants and juice factories belonging to agricultural holding companies, which should increase the latter's production capacity and provide income stability for the former.

\subsection{Regarding organic agriculture development}

In this difficult period of economic and social instability in Ukraine, the government's active leadership is urgently needed, particularly in agricultural and rural development. The development of organic agriculture based on small and medium-sized farmers and the family farm model currently appear the most effective instrument for the Ukrainian government based on the experience of developed countries. Given that Ukraine already has a dual agricultural system with big agricultural holding companies engaged in export activity, the government should provide support for small and medium-sized farmers and help them to develop in organic agriculture direction, as in the case of European countries and South Korea. The completion of a legislative and regulatory framework should help to define the state policy on organic production, create necessary conditions for the legal recognition and protection of organic products, form a national certification system, and set relevant rules and standards (FAO, 2012).

Today, all organic production in Ukraine is export-oriented and based on the production of organic grain crops intended for the EU. Unlike other European countries, Ukraine has no specialized shops or markets for healthy organic products. In addition, the processing industry is almost non- 
existent. Small private organic farmers typically sell their products to customers through traditional markets, and sellers generally have only a vague idea about what certified organic products are (UNEP, 2011). The transition from conventional to organic farming in Ukraine has slowed sharply because of a lack of marketing and advertising for healthy organic products. Thus the development of a domestic market for organic products can be achieved only by promoting economic benefits of organic production by farmers and owners of supermarkets as well as by advertising and increasing customers' awareness of sustainable and healthy lifestyles, including a balanced diet. It should be noted that the European trend in well-being is becoming more popular among Ukrainian consumers and there is some shift toward the purchase of healthy food. An increasing number of people are able and willing to spend more money for a balanced diet, particularly for the purchase of healthy food for children, which means that the child nutrition industry can benefit greatly from organic products. Unfortunately, such trends are not sufficiently reflected in the media, which typically focus more on advertising medicines than on promoting healthy lifestyles. This important issue should be addressed to the government. To increase consumers' awareness of organic products and create their demand for these products, there is a need to carefully analyze the experience of developed European countries and launch an information campaign through the media to promote healthy organic products and traditional dishes instead of junk food.

Promotional activities can encourage healthy nutrition and increase production, thereby indirectly influence development of domestic processing facilities. Intensive marketing activities for organic products through stock sales and supermarkets have the potential to create and strengthen the domestic market igniting and increasing end users' demand. Potential challenges may only arise from the limited variety of domestic organic products. Valuable marketing strategies can be offered by Germany, where organic farmers have formed an association to promote organic products and create common trademarks and brands for environment-friendly and healthy organic products distributed through the shops and restaurants (BMEL, 2018). In the Netherlands, farmers have organized dairies through which they produce traditional cheeses and quark made of organic milk and sell them through the small stores right on their farms or in neighboring villages (Afanasyev, 2010). Apart of being highly profitable for farmers themselves, such activities may play important role in the promotion of green tourism. Cooperation of organic farmers with different public and private enterprises such as schools and hospitals in the food/nutrition industry, is important for marketing organic products. It is clear that such measures require more funding, which is not possible in Ukraine without foreign investment.

\subsection{Regarding the role of local governments}

After signing the EU agreement, Ukraine's central and local governments have faced a new challenges in the area of new principles of competition, procedures, and standards. Rural inhabitants and investors have high expectations of better-quality services by local governments. To attract potential investors to rural areas, local governments should provide a wider range of support instruments for entrepreneurship development, including low taxes, customer-friendly services, partner relationships, and efficient and formal transactions. Another challenge lies in the development of basic infrastructure systems such as roads, schools, water supply systems, and sewage systems. To make such activities successful, local governments should design appropriate projects supported by local partners and manage the whole undertaking in an efficient manner (Sakowicz, 2007). Therefore local governments should be given more authority and be allowed to use the money, received from agricultural holding companies, and other taxes, to restore social infrastructure systems and for other needs. The government should enable citizens to participate more actively in its "governance." Therefore continuation of decentralization reform is very important. Another important issue for the government to consider is the regulation of land issue. Terminating the moratorium on land sales is possible only after settlement legislation, price regulation, and the creation of an agency overseeing this process. 


\subsection{Regarding rural development}

Based on the South Korean and E.U. experience, it can be seen that Ukraine's rural development policy should be more socially inclusive. Rural communities should be at the center of government support. In working with villagers, the government should enable village communities and encourage them to diversify their activities. According to the State Statistics Committee of Ukraine, formal employment among rural residents declined by $30 \%$ in the last decade of the 20th century (Afanasyev, 2010). Therefore, a solution may lie in cooperation between the agricultural and other sectors. Most of Ukraine's surplus labor has been involved in farming on individual land plots. However, with about a quarter of Ukraine's labor residing in rural areas, subsistence farming cannot be regarded as a sustainable solution.

Therefore, appropriate employment policies for surplus rural labor and an enhanced quality of life for rural residents as well as a more favorable environment for generating new jobs can be the major goal of any new rural development program. Looking on experience of EU countries Ukrainian government need to increase the level of effective employment and foster small and medium-sized farming development in rural areas. The development of rural non-farm employment opportunities can be seen as a pillar of the rural development policy and a critical factor in providing rural employment with stable income in the long term. Rural non-farm employment includes all economic activities associated with work, either salaried or selfemployed, located in rural areas (except for agricultural hunting and fishing) that contribute to a sustainable livelihood strategy for the rural population. This is important for rural areas, particularly for agriculture, because one of the most challenging adjustments facing Ukraine's agricultural sector today is the need to reduce hidden unemployment. In this regard, agricultural tourism may provide a good opportunity. Ukrainian villages, particularly those in the western part of the country, have valuable natural and agricultural resources such as intact forests, rivers, and fertile soil along river valleys. In these areas, rural tourism can be an important part of rural development. As a key sector of the economy, tourism creates jobs and makes positive contributions to the development of rural communities. In addition, it can stimulate the renewal of villages and make them more attractive as places to live and visit while contributing to the preservation of cultural heritage (Skryzhevska and Karácsonyi, 2012). With the development of rural tourism, other related business opportunities such as hospitality and sustainable agriculture can be pursued to benefit the local communities.

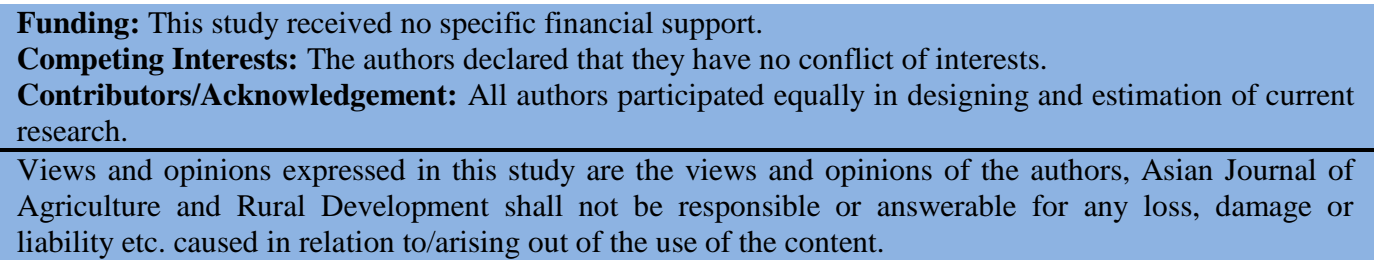

\section{References}

Afanasyev, V. (2010). Evaluating Ukraine's agro-industrial sector: comprehensive assessment with the view of sustainability improvement and European integration. 15.09.2010, LS Umweltplanung. view at Google scholar

Deininger, K., \& Byerlee, D. (2012). The rise of large-scale farms in land-abundant developing countries: does it have a future?. World Development, Elsevier, 40(4), 701-714. view at Google scholar

European Commission Agriculture and Rural Development (2007). The common agricultural policy explained, publication KF-77-07-075-EN-D. view at Google scholar

Food and Agriculture Organization of the United Nations (2012). The European Union's neighborhood programme assessment of the agriculture and rural development sectors in the Eastern partnership countries Ukraine, publication by FAO. 
Federal Ministry of Food and Agriculture (2018). Organic farming in Germany. brochure printed by the Federal Ministry of Food and Agriculture (BMEL), 2018. Retrieved from https://www.bmel.de/SharedDocs/Downloads/EN/Agriculture/OrganicFarming/OrganicFarming-in-Germany.pdf?_blob=publicationFile.

Hanushchak, Y., Sydorchuk, O., \& Umland, A. (2017). Ukraine's most underreported reform. New Eastern Europe. Retrieved from http://neweasterneurope.eu/2017/04/13/ukraine-smost-underreported-reform-decentralisation-after-the-euromaidan-revolution/.

Im, J. B., \& Jeong, I. J. (2014). The frame of agricultural policy and recent major agricultural policy in Korea. FFTC-COA international workshop on collection of relevant agricultural policy information and its practical Use, June 23-27, 2014, Taipei, Taiwan R.O.C. view at Google scholar

Kalinchyk, M. V. (2013). Growth strategy of agricultural sector of economy of Ukraine: does it exist?. Effective Economy, 10, 338-242. 4:631. Retrieved from http://www.economy.nayka.com.ua.

Kata, R., \& Zając, D. (2007). Role of territorial government in the development of agriculture and non-agricultural entrepreneurship in rural areas. University of Rzeszów, Faculty of Economics, 8(2), 23-31. Retrieved from https://ageconsearch.umn.edu.

Keyzer, M., Merbis, M. D., Witt, R., Heyets, V., Borodina, O., \& Prokopa, I. (2012). Farming and rural development in Ukraine: making dualisation work, report prepared by European Commission Joint Research Centre (JRC). Retrieved from http://publications.jrc.ec.europa.eu/repository/bitstream/JRC80164/jrc\%2080164.pdf.

Kim, K. U. (2009). Farm mechanization policies in Korea. Engineering in Agriculture, Environment and Food, 2(4), 132-143. view at Google scholar

Kolodiy, M. (2013). Modern tendencies of agroholding development in Ukraine. Collection of scientific works of the Tavria State Agrotechnological University (Economic Sciences), 2(22), 7-13. view at Google scholar

Kutsmus, N., Kovalchuk, O., \& Dankevych, V. (2017). Agricultural development in Ukraine: institutional changes and socio-economical results. KNUV, 2(55), 84-99. view at Google scholar

Lukerya, I., \& Halushka, O. (2016). Decentralization as a remedy for bad governance in Ukraine, Euromaidan Press. Retrieved from: http://euromaidanpress.com/2016/12/05/decentralization-governance-ukraine-reform/.

Maynzyuk, K., \& Dzhygyr, Y. (2008). Positioning LGI/OSI policy dialogue to support decentralization in Ukraine. Budapest: local government and public service reform initiative of the open society institute. view at Google scholar

Ministry of Agrarian Policy and Food of Ukraine (2015). Strategy for agriculture and rural development 2015-2020. Retrieved from http://minagro.gov.ua/en/node/15990.

Moroz, S. (2013). Rural households in Ukraine: current state and tendencies. Economics of Agriculture, UDC: 631.111.11(477), pp. 565-584. view at Google scholar

Norton, D. (2004). Agricultural development policy: concepts and experiences. Food and Agriculture Organization of the United Nations. view at Google scholar

Organization for Economic Co-Operation and Development (1999). Review of agricultural policies in KOREA, OECD Publications Service. view at Google scholar

Organization for Economic Co-Operation and Development (2004). Achieving Ukraine's agricultural potential stimulating agricultural growth and improving rural life. OECD Publications Service. view at Google scholar

Organization for Economic Co-Operation and Development (2010). Agricultural policies and rural development: a synthesis of recent OECD Work. OECD Publications Service. view at Google scholar

Sakowicz, M. (2007). Modernization of the process of integration of the poles in Europe and the European Union (Modernization of territorial government in the process of Poland's integration with the EU)', SGH, Warszawa, s. 9-10. view at Google scholar 
Sarna, A. (2014). The transformation of agriculture in Ukraine: From collective farms to agroholdings, OSW Commentary Centre for Eastern Studies 127, 1-11. Retrieved from https://library.westernsydney.edu.au/main/sites/default/files/pdf/cite_APA.pdf.

Skryzhevska, Y., \& Karácsonyi, D. (2012). Rural population in Ukraine: assessing reality, looking for revitalization. Hungarian Geographical Bulletin, 61(1), 49-78. view at Google scholar

United Nation Environment Programme (2011). Organic agriculture a step towards the green economy in the eastern Europe, Caucasus and central Asia region case studies from Armenia, Moldova and Ukraine, report prepared by Gunnar Rundgren, UNEP. view at Google scholar 